\title{
Influence of Cleanliness on Learners Learning Capabilities and Academic Performances: A South African Perspective
}

\author{
Chinaza Uleanya \\ Department of Educational Management and Leadership, University of Johannesburg, South Africa
}

Received August 18, 2020; Revised September 23, 2020; Accepted October 19, 2020

\section{Cite This Paper in the following Citation Styles}

(a): [1] Chinaza Uleanya, "Influence of Cleanliness on Learners Learning Capabilities and Academic Performances: A South African Perspective," Universal Journal of Educational Research, Vol. 8, No. 11B, pp. 5934 - 5942, 2020. DOI: 10.13189/ujer.2020.082228.

(b): Chinaza Uleanya (2020). Influence of Cleanliness on Learners Learning Capabilities and Academic Performances: A South African Perspective. Universal Journal of Educational Research, 8(11B), 5934 - 5942. DOI: 10.13189/ujer.2020.082228.

Copyright $\mathrm{C} 2020$ by authors, all rights reserved. Authors agree that this article remains permanently open access under the terms of the Creative Commons Attribution License 4.0 International License

\begin{abstract}
Cleanliness which promotes good health in learners in schools has become paramount considering the outbreak of the Covid-19 pandemic and its adverse effects on learners learning abilities and success. Also, cleanliness seems to have a link with security. Hence, the study explored the connection between cleanliness, security and the learning abilities of learners. In other words, attempt was made to investigate the relationship that exists between cleanliness in classroom, school environment, learners' habit and their academic performances. Qualitative method was adopted for the study. Purposive sampling was used to select three rural and three urban schools in KwaZulu-Natal Province of South Africa. Meanwhile, convenience sampling was used to select six educators who participated in the study. Semi-structured interviews were employed for data collection. The findings of the study suggest firstly that there is a link between security and cleanliness, and such is the reason why most urban high schools experience more cleanliness than their counterparts in rural communities. Secondly, cleanliness is a contributory factor which enhances the learning abilities of learners. Cleanliness which is upheld more in urban high schools compared to rural based high schools contributes towards boosting teaching and learning activities as well as the academic performances of learners. The paper therefore recommends amongst others that better security should be considered in and for rural based high schools. Cleanliness should be treated with esteem in high schools and at all
\end{abstract}

levels. Also, learners should be taught personal hygiene as one of the co-curricular subjects.

Keywords Cleanliness, Learners' Academic Performances, Learners' Learning Abilities, Rural High Schools, Urban High Schools

\section{Introduction}

Learning remains a major constraint for learners in different parts of the environment, especially in rural societies [1, 2,3,4,5]. Various factors have been explored on the causes of learners' challenges with regards to their learning abilities. For instance, [2] emphasise that the issue of quality in the provided education is a major constraint affecting the learning capabilities of learners. From a review of the work of [6], it can be deduced that unrest can be a major factor affecting the learning abilities of learners. According to [7], the issue of leadership is to explored as they opine that the place of the principals of schools cannot be overemphasised. Also, classroom management of educators, especially female educators is explored as a factor which can hamper or promote the learning abilities of learners [8]. According to [9], the perceptions of subject advisers as well as school management team members have the potential to hamper 
or promote the learning abilities of learners. Following a review of the work of [10], it can be inferred that the distance to school from where learners live is capable of contributing positively or negatively to their learning abilities. Meanwhile, [11] state that household poverty and the socio-economic background of learners can be a contributory factor to the learning abilities or deficiencies of learners. Ref. [12, $10 \& 13]$ state that the use of Learning and Teaching Support Materials (LTSMs) affect the learning abilities of learners. Sequel to a different perspective, [14] and [6] opine that the demography of learners and the timetable of teaching and learning activities are to be explored as they have the capability of contributing positively or negatively to the learning abilities of learners. From the foregoing, it is evident several factors contributing to the learning abilities of learners have been explored. The identified factors: quality of education, leadership and other Learning and Teaching Support Materials (LTSMs), amongst others are considered factors which distinguish urban based high schools from their rural counterparts. However, little or no research seems to have been undertaken on the issue of cleanliness and its effect on the learning abilities, consequently academic performances of learners. Hence, the reason for this study which aims at exploring the nexus between cleanliness and the learning abilities of learners with emphasis on rural is based high schools.

Ref. [15] conducted a study on the influence of clean school environment and standard classroom size facilities on the achievement of students in Biology. The finding of the study reveals that cleanliness has significant impact on the academic performance of students in Biology. The study however, only focused on one subject, not the general academic performance of the students. Similarly, [16] conducted a study on the perspectives of students with regards to the impact of cleanliness of university facilities on academic achievement, using a selected public institution of higher learning in Kenya. The findings show that cleanliness contributes to the qualification of students. For instance, majority felt that they would have gained better qualifications if their campus residences, halls and general environment of the institution were cleaner than what was obtainable during that period. However, the study only focused on the views of students in a public university. The location of the university: urban or rural was not taken into consideration.

Furthermore, according to [17], cleanliness can be promoted in class and school environment regardless of the location. Community Health Network opines that such can be done through the following ways:

1. By educating learners about appropriate hygienic culture such as good hand washing. They state that in this regard, tips like washing between the fingers and washing for sufficient time can keep germs out of the classroom and consequently the school environment.
2. Stocking up on supplies for cleaning. Materials such as tissues, disinfectant wipes, hand sanitizer among others are expected to be made readily available every school day. Ref. [17] hold the view that it is not enough to teach learners about cleanliness, and possibly show them how to maintain such healthy nature without making available the materials which will necessitate such desired lifestyle.

3. Dusting of shared objects in the classroom or school environment. Germs are transmitted from persons to persons through different means which may include passing on or sharing of common objects. Hence, [17] states that whenever learners have cause to share objects like writing utensils, desks, keyboards, chairs, among others, they should learn to clean the items properly, and where possible sanitize them. They stress that such items when not properly cleaned can pass germs off to many learners each day.

4. Discussing of healthy behaviour with learners in class and within the school premises is to be encouraged and promoted [17]. Community Health Network further opines that nothing should be overlooked. In fact, subject matters like getting enough sleep and staying hydrated can help keep learners' immune system strong, thus should be discussed and encouraged.

5. Encouragement of parents and guardians to keep sick children and wards at home. Community Health Network states that a system which will help to ensure sick children receive their schoolwork in order not to lag behind the curriculum is to be put in place. By so doing, sick children will not lose out much academically. In this regard, parents and guardians will be quite comfortable to keep sick children at home. This will help prevent the spread of any form of sickness and disease that may be suffered by the children. Moreover, children are vulnerable and can easily contract sicknesses or diseases if not prevented.

6. The Community Network states that sofas and carpets can be used as a hotbed to prevent germs. This is because they are easy to clean compared to objects like rugs. In brief, Community Health Network encourages the use of substances that can be easily cleaned and maintained for learners, whilst still upholding beautification values.

7. Teachers are to ensure that learners wash their hands after any form of recess or lunch before returning to the classroom. This implies that for every time learners are given recess by their educators and they are allowed to play around within or outside the classroom, their hands are to be washed. By so doing, personal hygiene is promoted.

8. Ref. [17] states that learners should be taught and made to practice the "Dracula sneeze." This is when people sneeze into the crook of their elbow. When learners do this in class or within the school premises, 
they prevent the airborne germs released during sneezing from spreading.

9. Additionally, learners should be educated about germs. The [17] categorically explain that educators can teach their learners about germs by pouring glitter onto the hands of some of their learners, ask them to shake hands for some minutes and watch the extent to which the "germs" can spread. Following this practical approach, learners can be taught the seriousness involved in the subject matters "germs and hygiene".

10. Sanitizing of the classroom with disinfectants at the end of each day. In this instance, different parts of the classroom including the doorknobs and other locks are not to be left out. This is envisaged to aid cleanliness and help learners stay healthy, while preventing diseases and sicknesses.

On the other hand, [18] corroborates the submission of [17]. Meanwhile, [18] adds that cleanliness in schools helps to ensure the following: better learning environment for learners, healthier school building. These in turn ensure fewer absences and sick days both for teachers and learners, consequently, it promotes academic success. Following the points raised by [17] and [18], cleanliness has great impact on the learning abilities of learners. Cleanliness seems to play a pivot role in enhancing the learning abilities of learners. Ref[19] further states that the points raised by [17] and [18] can be accomplished if the following are duly considered and put in place: orientation programmes should be duly organised promptly to help educate both learners and teachers on the necessary steps to be taken towards ensuring cleanliness. Such orientation programmes are to be well supervised by appropriate authorities. However, the issue remains whether educators, learners and other education stakeholders consider such phenomenon (cleanliness) as important, and where they do, what do they do to ensure such: promoting cleanliness and good academic performance from learners. Hence, the reason for this study which investigates the connection between cleanliness in schools and the learning abilities of learners, while exploring the subject matter from both urban and rural high school backgrounds. In order to achieve the aim of this present study, attempt was made to proffer answers to the following questions: does cleanliness contribute to learners' learning abilities and academic performances in the selected high schools? What affects or contributes to cleanliness? How can cleanliness be improved in the selected high schools?

\section{Conceptualization of Terms}

Rural environments vary from one nation to another. According to [20], rural environments in developed nations differ from developing or underdeveloped nations. For instance, they opine that rural environments in developed nations are characterized by lack of rail and air transport, whereas the experience is different in developing or underdeveloped nations which comprise many African nations. According to [21], quoted in [22], rural environment in the United States of America are separate areas or towns where the residents are below 2500 in population and are 30 miles away from urban areas. Ref. [23] as well as [22] state that certain factors should be considered when attempting to define rural environment. These factors include: size, culture, geographic location, accessibility to services and social amenities considered expedient in urban areas, population concentration to labour market and settlement, amongst others. Ref. [24] opine that rural areas in developing or underdeveloped areas like many sub-Sahara African nations are characterised by the following: high rate of under-employment and unemployment, illiteracy, associated with agriculture, poor socio-economic standard of living, amongst others. This implies that the level of development experienced in such areas is minimal compared to what is obtainable in urban centres. This supposedly accounts for one of the reasons behind the establishment of rural institutions of learning. Ref. [25] state that rural institutions of learning inclusive of rural high schools are centres that are strategically established in specific locations with the aim of reducing or possibly eradicating illiteracy and enhancing desired developments in such communities. Conversely, urban high schools are institutions of learning that are established in urban centres where relevant desired basic amenities are enjoyed. Ref. [24] aver that it is the desire to enjoy the satisfaction that comes with the supply of the relevant basic social amenities and the type of education provided that causes rural-urban migration. Ref. [3] had earlier opined that the quality of education provided in such environments has impact on the learning abilities of learners. Suffice it to say that there seems to be disparities in the forms of education provided in rural and urban areas. Whilst, the former tends to lack the desired quality, the latter tends to enjoy quality in various forms ranging from the provision of the necessary relevant structures and materials to the adopted teaching approach. Thus, the reason for this study, which aims at exploring the connection between cleanliness maintained by learners in selected urban and rural high schools in South Africa and their learning abilities, as well as their academic performances.

Cleanliness according to [17] [18] and [19] implies promoting hygiene in classroom and school environment in order for success to be achieved. In this study, cleanliness is used to mean hygiene in classrooms and school environments. The crux of this paper was to investigate the effect cleanliness contributes to the learning abilities of learners. Meanwhile, some previous studies on cleanliness and its link to success are presented in the table below. 
Table 1. Previous works and outcome

\begin{tabular}{|c|c|c|}
\hline $\begin{array}{c}\text { Author } \\
\text { and Year }\end{array}$ & Purpose & Findings \\
\hline [15] & $\begin{array}{c}\text { Influence of clean school } \\
\text { environment and standard } \\
\text { classroom size facilities on } \\
\text { the achievement of students } \\
\text { in Biology. }\end{array}$ & $\begin{array}{c}\text { Cleanliness affects } \\
\text { the academic } \\
\text { performance of } \\
\text { students in Biology. }\end{array}$ \\
\hline \multirow{5}{*}[17]{} & $\begin{array}{c}\text { Promotion of cleanliness in } \\
\text { class and school environment. }\end{array}$ & $\begin{array}{c}\text { Ways of promoting } \\
\text { hygiene in } \\
\text { classroom and } \\
\text { school environment } \\
\text { in order for success } \\
\text { to be achieved. }\end{array}$ \\
\hline \multirow{5}{*}[16]{} & $\begin{array}{c}\text { The perspectives of students } \\
\text { on the impact of cleanliness } \\
\text { of university facilities on } \\
\text { academic achievement, using } \\
\text { a selected public institution of } \\
\text { learni8ng in Kenya. }\end{array}$ & $\begin{array}{c}\text { Majority of the } \\
\text { students believed } \\
\text { that cleanliness } \\
\text { contributes to their } \\
\text { qualification. }\end{array}$ \\
\hline
\end{tabular}

\section{Methodology}

Constructivist paradigm was adopted in this present study. Hence, qualitative method was used for data collection. Ref. [26] and [27] support that when constructivist paradigm is adopted in a study, qualitative method is to be used for data collection. In congruence with [26], [27] and [28] opine that the use of qualitative method for data collection in a study aids the collection of in depth information over a subject matter. Based on the nature of this study, qualitative method was used for collection of in depth information from participants on the subject matter on the link between learners' cleanliness, their learning capabilities and consequently academic performances. Semi-structured interviews were used for data collection. Purposive sampling was used in selecting the high schools. The selected schools were categorised into three (3) urban and three (3) rural. Participants of the study were conveniently selected, based on their schedule, and availability to take part in the study. The participants of the study comprised 3 educators from 3 urban based high schools and 3 educators from 3 rural based high schools. In all, 6 conveniently selected educators were adopted for this present study. Meanwhile, qualitative method was adopted in the study in order to give participants opportunity to express themselves on the subject matter. This was done through semi-structured interviews which were conducted for each participant in their various schools. The selected sample of the study is as shown in table 2.

Table 2. Sample Size

\begin{tabular}{|c|c|c|}
\hline $\begin{array}{c}\text { Location of } \\
\text { School }\end{array}$ & $\begin{array}{c}\text { Number of selected } \\
\text { schools }\end{array}$ & $\begin{array}{c}\text { Number of selected } \\
\text { Educators }\end{array}$ \\
\hline Rural Schools & 3 & 3 \\
\hline Urban Schools & 3 & 3 \\
\hline Total & 6 & 6 \\
\hline
\end{tabular}

\section{Instrument}

Semi structured interviews were conducted for 6 conveniently selected educators in order to elicit in-depth information about the subject matter. The lecturers were conveniently selected based on their time, schedule, availability and interest to participate in the study. The responses retrieved through the semi- structured interviews conducted for the selected educators were used to proffer answers to the identified research questions guiding the study.

\section{Analysis}

The collected data were coded and analysed following responses of interviewees to the identified research questions guiding the study.

\section{Results}

The findings of this study are presented using the research questions guiding the study. The responses of the interviewed educators are marked using "UER" which is used to mean 'Urban Educator Response' and "RER" which is used to mean 'Rural Educator Response'. Meanwhile, the transcript is included in this paper as an appendix.

Table 3. The demographic data of participants in the study

\begin{tabular}{|c|c|c|c|c|}
\hline DEMOGRAPHICS & \multicolumn{2}{|c|}{ Urban } & \multicolumn{2}{c|}{ Rural } \\
\hline & $\begin{array}{c}\text { Frequency } \\
(\mathrm{N}=3)\end{array}$ & $\begin{array}{c}\text { Percent } \\
(\%)\end{array}$ & $\begin{array}{c}\text { Frequency } \\
(\mathrm{N}=3)\end{array}$ & $\begin{array}{c}\text { Percent } \\
(\%)\end{array}$ \\
\hline GENDER & 1 & 33.3 & 1 & 33.3 \\
\hline Male & 2 & 66.7 & 2 & 66.7 \\
\hline Female & & & & \\
\hline ETHNICITY & 3 & 100 & 3 & 100 \\
\hline Black & & & & \\
\hline
\end{tabular}

Research Question 1: does cleanliness contribute to learners' learning abilities and academic performances in the selected high schools?

The finding of the study following the first research question suggests that availability and the state of conveniences in rural high schools contributes to the level of cleanliness experienced by both learners and educators as well as the learning abilities of learners. For instance, UER1 responded by saying: Yes. Effective teaching and learning can easily be attributed to a clean environment and thus enhance learner's learning ability. In congruence, UER2 said: Of course, it does, I cannot and will not teach in a dirty class, same way, I do not expect my learners to learn in such environment. UER3 also added by saying: Definitely it does. Cleanliness has a great contribution in the development of a child's mind, it brings confidence and 
feeling of competence, which impacts academic performance. Also the work a learner presents often displays his or her cleanliness.

Also, the finding suggests that the availability of clean toilets with mirrors in urban based high schools may constitute some forms of distractions for learners. RER2 said that: To a large extent toilet cleanliness also affects teaching and learning. However, UER2: I think it does, as most learners would not like to use a dirty toilet, but also clean toilet might have its own problems, learners often visit clean and mirrors toilet which causes disruption during lessons. The concentration of learners during lesson can be disrupted when learners keep on approaching educator for permission to go to toilet. This implies that while rural based high school learners are most likely to suffer from lack of clean toilets, their counterparts get distracted due to the provision of clean toilets with other facilities. The finding on the lack of availability of clean toilets in rural based high schools agrees with the 2018 report of the [29] which indicates that 620 million children are in danger due to lack of toilets. Similarly, the report submitted by [30] suggests that KwaZulu-Natal is one of the provinces in South Africa where toilet is one of the major challenges experienced in rural schools. The report further indicates that where toilets and other infrastructures are available, issues of lack of security which makes unrest uncurtailable affects and also leads to the destruction of such facilities. This indicates that whilst scarcity of toilets in rural high schools affects teaching and learning activities, lack of security leads to the destruction of others where they are available.

\section{Research Question 2: What Affects or Contributes to Cleanliness in your school?}

The responses of interviewees with regards to this question are as presented below:

This finding of the study suggests that cleanliness in schools is a task for different education stakeholders such as learners, educators, school authorities, community members, amongst others. For instance, UER1: Different factors contribute to cleanliness in our school. Educators, learners, School Governing Body (SGB), parents and all others who have dealings with the school. This finding suggests that everyone who has dealings with the school has the potential to contribute to cleanliness. Two participants also said that: RER1: Upbringing plays a major role, if a learner comes from a clean home, the learner will keep up or will maintain the standard from home. Also, the environment does contribute.

RER2: Community members have so much influence on what happens in our school. Their activities, support or otherwise, affect cleanliness one way or the other in our school. For example, sometimes, we buy materials that can help us in enhancing cleanliness, only for them to be stolen after we leave for home.
This finding coincides with the work of [17] who highlight various ways by which cleanliness can be maintained and promoted by different stakeholders within the school premises. They further state that parents who are also stakeholders can promote cleanliness by ensuring that learners are well handled at home with regards to issues surrounding cleanliness and healthy living.

\section{Research Question 3: How can cleanliness be improved in the selected high schools?}

This finding suggests that various schools have different mechanisms by which cleanliness are maintained and can be improved. However, monitoring is important. For instance, UER1 said that: "Cleanliness can be ensured by constant provision of the necessary cleaning materials and monitoring." From the words of UER3, it is deduced that monitoring to ensure cleanliness is part of the duties of the deputy principal in their school. Hence, UER3 said: "The deputy principal moves round towards the end of each school day to make sure learners clean their classrooms. This is a good practice; I think it will always help." Meanwhile, RER1 sees the subject of monitoring and ensuring cleanliness in school as part of the duties of educators. For instance, in RER1 said that: "Educators can constantly monitor their learners to practice personal cleanliness before proceeding to the classroom and entire school. This can be done through practical exercises." This finding coincides with [19] who states that monitoring is necessary towards ensuring and promoting cleanliness in schools. However, security is believed to be another strategy which is capable of aiding cleanliness in schools. For instance, RER2 says that: "The security of the school should first be improved, that way, we can be sure that any material provided by parents, the school or government for maintaining cleanliness in school can be safe." This finding corroborates [19] which considers safety and security as paramount in schools. The comments from the responses of interviewees are adopted as part of the recommendation from this study.

\section{Conclusion and Recommendations}

The study explored the connection between cleanliness and the learning abilities of high school learners, consequently, their academic performances. The findings of the study show that there are disparities on how cleanliness and security issues are handled in the selected urban and rural based high schools. Further findings of the study suggest that cleanliness has impact on teaching and learning activities, the learning abilities of high school learners in various ways, consequently, their academic success. Also, the finding of the study indicates that there is a connection between security and cleanliness in rural based high schools. Sequel to the findings of the study, the following recommendations are made: 
1. Cleanliness should be ensured within the classrooms, school premises, restrooms, amongst others. The restrooms can be kept clean by allowing learners and teachers to use the same place. In this regard, teachers will do all in their power to ensure that the restrooms are kept clean, unlike when there are separate restrooms, teachers may feel less concern about the cleanliness of the restroom of their learners. In this regard also, activities of learners around the restroom can be monitored.

2. The security of rural high schools should be treated as prime as it promotes cleanliness as well. For instance, when the security of rural high schools is in order, it will be difficult for edifices or items within the school premises to be vandalised or stolen. This will aid provision and safe keeping of necessary basic items enhancing cleanliness.

3. Learners should be taught personal hygiene as one of the co-curricular subjects. In this regard, learners will take issues of cleanliness more important and treat them as such. This will also aid practical application of cleanliness and improvement of personal hygiene. This can be done by giving time for seminars or workshops periodically: weekly or fortnightly.

4. Learners can be made to work on projects relevant to cleanliness either on individual or group base. This will aid their understanding on personal hygiene and cleanliness.

5. Appropriate hygienic culture such as good hand washing and sanitizing for sufficient time can keep germs out of the classroom and consequently the school environment. In other words, personal hygiene should be encouraged and promoted.

6. Providing cleaning materials such as tissues, disinfectant wipes, hand sanitizer among others is expected to be made readily available.

7. Shared objects in the classroom and school environment should be dusted regularly.

8. Sick and vulnerable children should be encouraged and made to stay at home.

9. Classrooms and the school environments should be sanitized with disinfectants at the end of each day. In this instance different parts of the classroom including the doorknobs and other locks are not to be left out. This is envisaged to aid cleanliness and help learners stay healthy, while preventing diseases and sicknesses.

Meanwhile, based on the fact that the study was limited to only selected high schools in one province in South Africa, it is suggested that similar study can be replicated using two or more provinces, nations or continents. This will help to juxtapose happenings within and outside provinces, nations and continents.

\section{Acknowledgments}

The researcher will like to acknowledge and appreciate the department of Social Science Education, faculty of education and research office of the University of Zululand, KwaDlangezwa, KwaZulu-Natal, South Africa, as well as the department of Education Leadership and Management, Auckland Park, Gauteng, South Africa for supporting this research in various ways.

\section{APPENDIX}

The responses of interviewees with regards to research question 1 are as presented below:

UER1: Yes. Effective teaching and learning can easily be attributed to a clean environment and thus enhance learner's learning ability.

UER2: Of course, it does, I cannot and will not teach in a dirty class, same way, I do not expect my learners to learn in such environment.

UER1: Cleanliness for me begins with the learners themselves, if they fail to maintain personal hygiene, the state of their health can be affected and certainly, they may eventually have to absent themselves from school. That way their learning abilities can be affected as well as their academic performance.

UER3: Definitely it does. Cleanliness has a great contribution in the development of a child's mind, it brings confidence and feeling of competence, which impacts academic performance. Also, the work a learner presents often displays his or her cleanliness.

UER3: ...imagine all of us undertaking teaching and learning exercises, how convenient will that be? What will happen to the teacher and learners? How well will they enjoy such activity? That's my response on this.

UER2: Cleanliness affects a person`s personality, people do not want to associate themselves with a person who is unhygienic, it also helps in elevating self-esteem in learners. A learner may put more effort in his or her work boosted by their appearance. You may be chosen for any position such as Representative Council of Learners (RCL) in school because of your cleanliness. When you are clean you most likely have an acceptable behaviour.

RER2: Yes (indirectly)

RER1: Yes, an unclean, untidy classroom and school environment can be very disturbing detrimental to school learners learning experience an unclean school can be a breeding ground for germs and illness. When learners are constantly getting sick, that means more time out of school will affect learner performance sickness absenteeism can be extremely detrimental to learner performance. When learners miss too much class, they may begin to fall behind with their school lesson that can affect performance. When learners are constantly getting sick, that means more time out of school while learners are trying to get help for their life. Lack of cleanliness can also be a major distraction to students. So much as an untidy classroom can distract learners from their teacher's lesson, with distraction only 
increasing the dirtier the facility. Children have enough trouble concentrating as it is, and don't need the extra distraction while they are trying to learn

RER3: Obviously, cleanliness contributes to the learning abilities of learners. Permit me to add that it contributes to the teaching abilities of educators. Like I can't teach in a dirty environment, the same way, I don't expect my learners to learn in similar environment.

RER2: Learning in an unclean environment is synonymous to writing continuously on the board without dusting. Untidy environments are enough distractions for both educators and learners. So in my own view, cleanliness can help educators and learners to focus more during teaching and learning activities.

RER3: Yes, it does because if the institution is clean, the learners' minds only concentrate on learning and the mind is also free from any disturbance, only concentrate on learning.

This finding shows that cleanliness is a contributory factor to teaching and learning in both rural and urban based high schools. This finding corroborates the works of [15] as well as [16] who opine that cleanliness contributes to the academic performances. Suffice to state that the clean or unclean state of the teaching and learning environment contributes positively or negatively to teaching and learning activities.

Further findings based on the responses of interviewees suggest that the clean state of the available convenience in the school also has effect on teaching and learning activities. Some of the responses are as presented below:

UER2: I think it does, as most learners would not like to use a dirty toilet, but also clean toilet might have its own problems, learners often visit clean and mirrors toilet which causes disruption during lessons. The concentration of learners during lesson can be disrupted when learners keep on approaching educator for permission to go to toilet.

UER1: Toilets affect teaching and learning in a positive way. If toilets are clean, then learners will feel comfortable and relaxed.

RER1: Imagine you are in class and have course to go use the toilet but remember that there is no restroom or comfortable place for one to release. Definitely, one will have to try to manage him / herself in class. I wonder how such a person will concentrate being uncomfortable in class.

RER1: Male learners and educators are lucky in this case, they can stand to urinate even when the place is dirty and stinking, but for us female learners, it is not so. This makes us sometimes try to manage ourselves in class and where we cannot, we go through serious inconvenience.

RER2: To a large extent toilet cleanliness also affects teaching and learning.

RER3: It is not easy to hold urine or excreta and learn in class at the same time just because there is no good toilet.

RER1: Sometimes, when I am pressed and remember that there is no suitable place to release the waste, I end-up try to hold it. Sincerely, one cannot teach in such instance.

RER2: For us male educators, it is fair, we can easily walk to a nearby bush and release the "waste product" but I know this is not convenient for female educators.

The responses of interviewees with regards to research question 2 are as presented below:

UER1: Different factors contribute to cleanliness in our school. Educators, learners, School Governing Body (SGB), parents and all others who have dealings with the school.

UER2: Learners contribute to cleanliness as well as the aunts employed to clean the school surroundings.

UER3: I believe that learner personal hygiene, avoidance of littering of the school compound, and the classrooms all contribute to cleanliness in our school.

RER1: Upbringing plays a major role, if a learner comes from a clean home, the learner will keep up or will maintain the standard from home. Also, the environment does contribute.

RER2: Community members have so much influence on what happens in our school. Their activities, support or otherwise, affect cleanliness one way or the other in our school. For example, sometimes, we buy materials that can help us in enhancing cleanliness, only for them to be stolen after we leave for home.

RER3: For me, I believe that desire for hygienic environment contributes to cleanliness in school.

RER1: ....things have improved in our school since the community decided to assist us with security during the day and at night. Sanity and cleanliness is getting better now.

RER2: Poor health, ignorance. If you are surrounded by dust, then you might have allergies and lung diseases. Untidiness not only affects you physically but also mentally. Untidiness may result in stress.

RER3: ... when the toilet is dirty or has no water learners are not going to use it. Learners have to (hold it in) because they know the toilet is not clean. They have to wait until they return home and (holding it in) can cause infection that can lead to illness.

The responses of interviewees on research question 3 are as presented below:

UER1: Cleanliness can be ensured by constant provision of the necessary cleaning materials and monitoring.

UER2: If educators and learners are sensitized to see the classrooms, and the school as theirs, cleanliness will be easily enjoyed.

UER3: The deputy principal moves round towards the end of each school day to make sure learners clean their classrooms. This is a good practice; I think it will always help.

UER2: In our school, educators and learners use the same toilets, males one side, and females the other side. This has helped in the maintenance of cleanliness in the toilet use. The same thing can be done in other areas which 
can help to aid adequate monitoring.

UER1: Workers have been employed to clean the compound twice in a week. Learners pick litters on compound when the need arises. Learners clean the classroom after school hours every day. Learner clean and polish the classrooms on Fridays.

UER3: High school educators emphasizing the importance of personal and environmental hygiene at home and school, better maintenance of and improved facilities, sanitary pads must also be made available for female learners.

RER2: The security of the school should first be improved, that way, we can be sure that any material provided by parents, the school or government for maintaining cleanliness in school can be safe.

RER1: Educators can constantly monitor their learners to practice personal cleanliness before proceeding to the classroom and entire school. This can be done through practical exercises.

RER2: It can be improved by ensuring that the cleaning material is always available and accessible. Learners should always be reminded about keeping the school clean, they should refrain from unnecessary littering.

RER3: We will need the community members and government to help us with the necessary structures like well-built toilet. This will be easy to maintain and will help us get better.

RER2: Community members, educators and learners can be made to know the dangers in lack of cleanliness. Maybe, that may help them to take the issue of cleanliness more serious.

RER1: Cleanliness need to be taken as a priority. For the school, there must be a regular check-up of roaster to clean places and schools should award learners for being clean and maintaining the places clean.

RER3: Regular monitoring and constantly preaching cleanliness to the selected high schools

\section{REFERENCES}

[1] C. Sehoole, M. Nkomo. Rural - based Universities in South Africa: Albatrosses or Potential Nodes for Sustainable Development? International Journal of Sustainability in Higher Education, Vol.8, No.2, 234-46. https://doi.org/10.1 $108 / 14676370710726689$

[2] S. Akoojee, M. Nkomo. Access and quality in South African higher education: The Twin Challenges of Transformation. South African Journal of Higher Education, Vol.21, No.3, 385-99. https://doi.org/10.4314/sajhe.v21i3.2 5712 .

[3] T. Lewin, M. Mawoyo. Issues and Interventions in South African Universities. Inyathelo: The South African Institute of Advancement, Pretoria, 2014.

[4] C. Uleanya, B.T. Gamede. Access with Success: Approach for Sustainable Social Changes in Developing African Societies: A Case Study of South Africa. The Anthropologist International Journal of Contemporary and Applied Studies of Man, Vol.30, No.3, 174-79. doi:10.1080/09720073.2017.1414328

[5] C. Uleanya, B.T. Gamede. Correlates of Pedagogic Malpractices. The Independent Journal of Teaching and Learning (The IJTL), Vol.13, No.2, 36-52

[6] C. Uleanya. Comparative Correlates of Campus Unrest Nexus Learning Abilities of undergraduates in South Africa and Nigeria. Journal of Gender, Information \& Development in Africa, Vol.8, No.1, 83-106 (DOI: https://doi.org/10.31920/2050-4284/2019/8n1a4)

[7] C. Uleanya, N.P. Khumalo, E. Momah, B.B. Ndlovu. Contextualising Leadership Paradigm as a Determinant for Academic Success: A Case Study of Secondary Schools in Nigeria and South Africa. Journal of Gender, Information \& Development in Africa, Vol.8, No.1, 188-207 DOI: https://doi.org/10.31920/2050-4284/2019/8n1a10)

[8] I.N. Sibiya, B.T. Gamede, C. Uleanya. Classroom Management Challenges Experienced by Female Educators in Rural Secondary Schools in South Africa. Gender \& Behaviour Journal, Vol. 17, No.2, 12894-909.

[9] V.T. Smith, B.T. Gamede, C. Uleanya. Subject Advisers' Perception of Curriculum Delivery in the Intermediate Phase in South Africa. Interchange (INCH), Vol.1, 1-11

[10] C. Uleanya, B.T. Gamede, M.O. Uleanya. Distance Nexus Learning Challenges among Rural Undergraduate University Students. Journal of Gender, Information \& Development in Africa, Vol.8, No.1, 129-44. https://doi.org/10.31920/2050-4284/2019/8n1a4

[11] O. Iwaloye, B.T. Gamede, C. Uleanya. Effects of Household Poverty Trap on Learners' Academic Performances: A Case of Rural High Schools in Nongoma Circuit of South Africa. Afrikka: Journal of Politics, Economic and Society, Vol.9, No.1, 139-65. DOI.org/10.31920/2075-6534/2019/9n1a7

[12] Bower, J. Poor Pedagogy + Technology $=$ Accelerated Malpractice. Online available from http://joe-bower.blogsp ot.com/2010/10/poor-pedagogy-technologyaccelerated.html

[13] S.O. Taiwo, C. Uleanya, M. Magigaba. Gender Comparative Analysis of the Impact of Smartphone as a Learning Tool. Journal of Gender, Information \& Development in Africa, Vol.8, No.1, 159-87

[14] C. Uleanya. Comparative Rural University Students' Demography Nexus Learning Abilities. Gender \& Behaviour Journal, Vol.16, No.3, 12035 - 12053

[15] J.A. Ogbeba, I.A. Muluku. Influence of Clean School Environment and Standard Classroom size facilities on Students' Achievement in Biology in Gwagwalada Area Council of Fct-Abuja. Case Studies Journal, Vol.1, 21-26.

[16] H. Kiplagat, J. Khamasi, J. Jelimo, A. Mokaya. Students' Perspective on the Impact of Cleanliness of University Facilities on Academic Achievement: A Case of a Public University in Kenya. African Journal of Education Science and Technology, Vol.3, No.3, 93-99.

[17] Community Health Network. 10 Tips for a Clean Classroom. 
Online available from https://www.ecommunity.com/health minute/2017/10-tips-clean-classroom.

[18] Atalian Global Services (AGS). The Importance of Cleanliness in School. Online available from https://atalian.ph/2020/01/17/the-importance-of-cleanlinessin-school/.

[19] Department of Basic Education (DBE). Coronavirus Orientation Guidelines for Schools: For Teachers, Support Staff and Learners On the COVID-19 Outbreak in South Africa. Department of Basic Education, Pretoria, 2020

[20] C.B. Flora, J.L. Flora. Rural communities: Legacy and change (4th ed.). Boulder, CO: Westview Press, 2013.

[21] B.A. Miller. Rural distress and survival: the school and the importance of community. Journal of Research in Rural Education, Vol.9, No.2, 84 - 103.

[22] S. Walters, L. Cooper, B. Barter. Rural education: learning to be rural teachers. Journal of Workplace Learning, Vol.20, No.7/8, 468-79.

[23] V. du Plessis, R. Beshiri, R. Bollman, H. Clemenson. Definitions of 'rural, Agriculture and Rural Working Paper Series No. 61, Statistics Canada, Ottawa, 2002.

[24] S. Mercandalli, B. Losch. Rural Africa in motion. Dynamics and drivers of migration South of the Sahara. Rome, FAO and CIRAD, 2017, 60.

[25] S. Dani, S. Shah. Call and Definition of Rural University. IOSR Journal of Economics and Finance, Vol.7, No.1, 64 66

[26] R. Kumar. Research Methodology A Step-by-Step Guide for Beginners. SAGE Publications, Los Angeles, 2014.

[27] J.W. Creswell. Research Design: Qualitative, Quantitative and Mixed Methods Approaches. 4th ed. Thousand Oaks, CA: Sage, 2014.

[28] F. Du Plooy-Cilliers, C. Davis, R. Bezuidenhout. Research Matters. JUTA, Pretoria, 2014.

[29] World Economic Forum. A lack of school toilets is putting 620 million children in danger. Here's what needs to be done. Online available from https://www.weforum.org/agenda/20 18/11/lack-of-school-toilets-puts-620-mln-children-in-dang er-report/.

[30] B. Louton, D.A. Still, A. Pearson, G. Sitholimela, T. Mphahlele, E. Shaylor. Exploring the Issues Around Rural On-Site School Sanitation in South Africa. A preliminary report to the Water Research Commission on Project K5/2381: Evaluating the design of existing rural school sanitation infrastructure and developing a model and guidelines for optimal design. South Africa: Water Research Commission, 2015. 